\title{
Drivers of the Distribution of Soil Organic Carbon Stocks in the Topsoil Under Pinus Hartwegii Lindl. Forest, Along an Elevation Gradient in Central Mexico
}

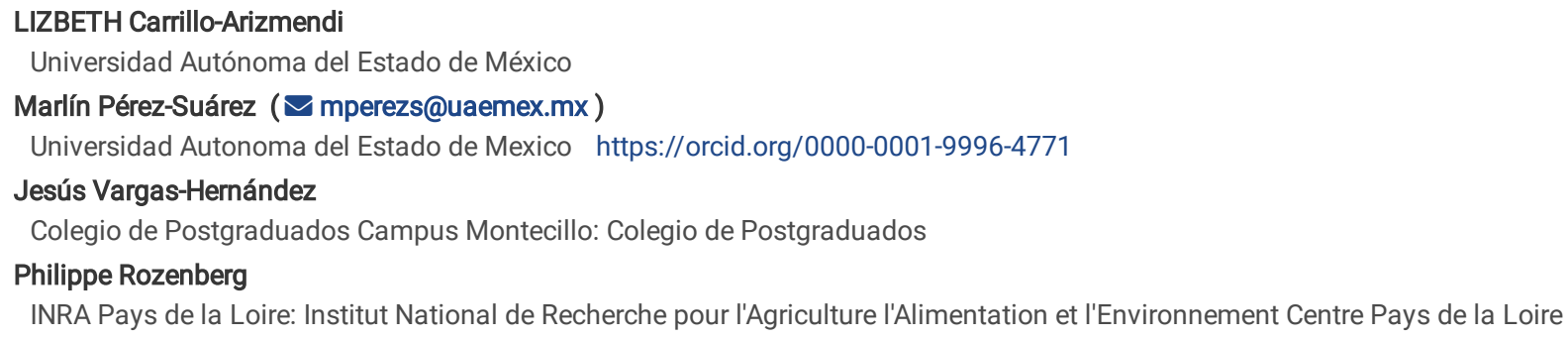

\section{Research}

Keywords: high mountain forest, climate change, low temperature, soil organic matter, elevation

Posted Date: August 3rd, 2021

DOI: https://doi.org/10.21203/rs.3.rs-754236/v1

License: (9) (1) This work is licensed under a Creative Commons Attribution 4.0 International License. Read Full License 


\section{Abstract}

Background: Mountain forest soils ( $\geq 2,500 \mathrm{~m}$ a.s.l. ${ }^{[1]}$ ), where elevation is crucial in the ecosystem dynamic, have a great capacity to capture and preserve carbon for a long time. The aim of this research was to determine the role of elevation combined with soil, climate, and vegetation variables on soil organic carbon (SOC) stocks distribution under $P$. hartwegii in the Nevado de Toluca Volcano, a protected area in Mexico. Topsoil samples (0-15 cm depth) collected every $100 \mathrm{~m}$ in elevation (3,400-4,000 m) were chemically and physically examined in statistical analysis together with vegetation structure and climate variables. Derived from field forest conditions, elevation plots were additional analyzed as logged (3,400-3,800 m) vs no-logged (3,900-4,000 m).

Results: SOC stocks followed a significant linear trend $\left(r^{2}=0.70 ; p=0.02\right)$ along the elevation gradient, being highest at 4,000 $\mathrm{m}\left(173.1 \pm 5.2 \mathrm{Mg} C\right.$ ha $\left.{ }^{-1}\right)$ and lowest at $3,700 \mathrm{~m}\left(146.8 \mathrm{Mg} \mathrm{C}^{-1}\right)$. Multiple regression analyses showed that SOM, BD, and mean annual temperature (MAT) were the main abiotic drivers of SOC stocks variability $(94.5 \%)$ along the elevation gradient. Meanwhile, from the logistic multiple regression, higher tree shrubs and herbs density, in addition to lower tree height and grass cover at lower elevations, indicate a significant effect of logging on soil traits and vegetation structure, depending on the elevation plot.

Conclusions: This research evaluated the SOC stocks and the potential effect of current warming over mountain soils, using the elevation as a proxy for both environmental and human drivers of SOC stocks in mountain forest ecosystems. Higher SOM and grass cover, larger-diameter trees together with low temperatures and logging restrictions in the high elevation range suggest a slower decomposition rate and SOC long-term stability. Despite the fact that we do not know about the intensity and cutting cycle, nor the size of the clearings derived from the trees removed, results from this research show how logging could exacerbate these effects and diminish SOC stocks, as well as the capacity of mountain soils to mitigate the effects of climate change.

\section{Background}

Mountain forests $(\geq 2,500 \mathrm{~m})$ account for $23 \%\left(9,000,000 \mathrm{~km}^{2}\right)$ of the Earth's forest cover (FAO 2011). These forests have been widely recognized for their role in regulating climate and water cycles, but little is known about the role that low temperatures could have in the carbon (C) cycle. At a global scale, forests are the major component of the $\mathrm{C}$ cycle on Earth, storing 1,146 Pg of C, with as much as two-thirds of this C in soils (Dixon et al. 1994). Mountain soils are expected to store more $C$ than soils in low-elevation forests $(<1,000 \mathrm{~m})$ (Spracklen and Righelato 2014; Swetnam et al. 2017), because lower temperatures promote $\mathrm{C}$ accumulation through lower decomposition rates (Wiesmeier et al. 2019). However, since mountain forests are considered among the most sensitive terrestrial ecosystems to climatic change (IPCC 2014; Pepin et al. 2015), there is great concern in potential C stock changes in mountain soils as temperature increases (Kirschbaum 2000; Heimann and Reichstein 2008), particularly in the tropics, where warming rates may be more severe at higher elevations (Beniston et al. 1997; IPCC 2014).

The rise of temperature (regional driver) could increase both SOC inputs and outputs in mountain ecosystems (Davidson and Janssens 2006; Wiesmeier et al. 2019) based on the two following opposite theories (Kirschbaum 2000; Berg and Meentemeyer 2002). The first hypothesis states that an increase in soil temperature will result in higher soil $\mathrm{CO}_{2}$ emission to the atmosphere (positive feedback) through accelerated SOM decomposition. The second hypothesis assumes an increase in soil nitrogen $(\mathrm{N})$ with faster SOM decomposition, resulting in greater plant productivity with higher litter production and $\mathrm{C}$ input to soil, rendering a negative feedback to the atmosphere. However, there is uncertainty on which will be the dominant underlying trend linked to warming, due to the great spatial heterogeneity in mountain forests and the possible influence of other factors.

Local effects of climatic change on SOC balance might depend on both biotic (plant species) and abiotic (soil type, soil depth, slope, elevation, etc.) conditions, as well as the interaction of both (Salome et al. 2010; Kumar et al. 2012; Bohra et al. 2014; Dymond et al. 2016). Some of these factors might play an important role in mediating SOC stability, i.e., SOC decomposition over the long term (Six et al. 2002; Tian et al. 2016). SOC stability is given through physical protection, as well as biological and chemical reactions. Physical protection of SOC is given by soil structures through aggregate formations, as well as by soil biota such as fungi, bacteria, roots, etc. (Six et al. 2002; Six et al. 2004; Wiesmeier et al. 2019).

Potential impacts of environmental warming on SOC stocks have been determined by using elevation gradients as a surrogate for temperature gradients, since they provide more realistic field conditions than manipulative experiments in laboratories (Körner 2007; Kumar et al. 2012; Tito et al. 2020). Previous studies using elevation gradients have identified different factors as main SOC drivers, including thermal gradients, plant communities, and other local factors (Jobbágy and Jackson 2000; Kumar and Lloyd 2012; Bohra et al. 2014; Maraseni and Pandey et al. 2014; de la Cruz-Amo et al. 2020). Moreover, different types of correlations have been reported between SOC stocks and elevation: negative (Sheikh et al. 2009; Kumar et al. 2012; Bohra et al. 2014; Shedayi et al. 2016), positive (Du et al. 2014; Tashi et al. 2016; Simon et al. 2018), and non-significant (Tewksbury and Miegroet 2007; Zhu et al. 2010; Zhang et al. 2011). For example, Tashi et al. (2016) attributed the direct relationship between SOC and elevation to the reduction in temperature and increase of precipitation, emphasizing temperature as the main driving factor of SOC accumulation along the gradient.

In contrast, Tewksbury and Miegroet (2007) found no interrelation between SOC and elevation, even though C accumulation in the forest floor was more abundant at higher (cooler) elevations, where $\mathrm{C}$ turnover was lowest. On the other hand, Shedayi et al. (2016) maintain that elevation controls SOC stocks through vegetation composition and structure, all linked to temperature reduction and increased elevation. In addition, other factors that modified vegetation structure such as harvesting and selective logging have showed to have a stronger effect in low forestlands than in higher terrains (Jafari et al. 2013). Neglect effect has also been reported to exert an effect over SOC stocks, despite severely diminishing OC in the topmost centimeters of soil (Nave et al. 2010; Chiti et al. 2016; Mayer et al. 2020). Nave et al. (2010), for example, mention that logging reduces SOC by 8 \% in temperate forests, while James and Harrison (2016), through a meta-analysis published in 112 research papers, pinpoint an average SOC stocks reduction of $11.2 \%$ around the world. The effects of logging on SOC stocks persist for a long time and reduction in SOC remains up to 45 years after logging (Chiti et al. 2016). 
More than 50 \% of Mexico's continental territory rises above 1,000 m (Challenger 1998), of which approximately $3.5 \%$ are Andosols (unaged volcanic soils) which contribute significantly to the mitigation of regional $\mathrm{CO}_{2}$, with high $\mathrm{OM}$ content and high $\mathrm{SOC}$ sequestration potential (Neall 2006). However, the relationships between SOC stocks and elevation-temperature have not been thoroughly studied in the Mexican mountains where Pinus hartwegii Lindl. is distributed. This mountain pine, with a wide elevation transect $(3,500-4,000 \mathrm{~m})$ for a single dominant tree species, provides an unrivaled opportunity for ecological studies along a wide elevation gradient. Under the climate change context, $P$. hartwegii has been reported as one of the most vulnerable species to the warming projections of climatic change models (Gómez-Mendoza and Arriaga 2007).

A reduction in the environmental suitability of the species has been reported, due to warming coupled with an upward redistribution (Cruz-Cardenas et al. 2016; Manzanilla-Quiñones et al. 2019; Alfaro-Ramírez et al. 2020), in addition to extensive human pressures such as extractive activities (legal or non-legal) and land-use change (Franco et al. 2006). Both events could have an important impact on modifying not only the local, regional, and whole range cover of $P$. hartwegii forests, but also through many other ecosystem services they provide, such as climate regulation and SOC storage. Therefore, it is important to consider the OC stored in the mountain forest soils in the $\mathrm{C}$ national inventories (Santini et al. 2019), and not only the $\mathrm{C}$ in the aboveground, as it has been done, as well as the effect of elevation on SOC pools, which would help to know the impact of warming on SOC stocks in these mountain forests.

In this sense, this research aims to evaluate the influence of elevation on SOC stocks and other soil properties along the elevation distribution gradient of $P$. hartwegii in the Nevado de Toluca, as well as to determine the main biotic and abiotic variables influencing SOC stocks in the topsoil of $P$. hartwegii using elevation as a surrogate for temperature to gain knowledge on the potential effects of warming on SOC stocks in this particularly important model of mountain forest ecosystems.

\section{Methods}

\section{Study sites}

The study was conducted at the Protected Area of Flora and Fauna (PAFF) Nevado de Toluca, an inactive volcano located east of the Transversal Volcanic Belt (19 06' 06" N 99 46' 03" W; Fig. 1 A, B and C), approximately 23 km southwest of Toluca City, State of Mexico in central Mexico. The dominant soil group, Andosols, covers $90 \%$ of the area (Fig. 1 C; INEGI 2007). The climate in the area is isothermal, with the highest temperature occurring before the summer solstice (June) (Fig. 2; Challenger and Soberón 2008). According to García (1990), in the Nevado de Toluca the average annual temperature (MAT) is reported between -2 and $5^{\circ} \mathrm{C}$. In the Tenango del Valle weather station at 2,560 m MAT is $13.23^{\circ} \mathrm{C}$, while at $4,139 \mathrm{~m}$, where the Nevado de Toluca station is located, it is $3.7^{\circ} \mathrm{C}$. Although rainfall can occur throughout the year, the rainy season extends mainly from May to October; July is the wettest month, with rainfall records over $90 \mathrm{~mm}$ per day (CONANP 2016). Snowfall is common in winter (December to February) at 3,700 m or higher (Challenger y Soberon 2008).

Dominant vegetation at the Nevado de Toluca changes with elevation; $P$. hartwegii forests dominate between 3,500 and 4,000 m. These forests are open communities with an arboreal stratum reaching 25-35 m height, although trees decrease in height and diameter towards the upper elevation limit (HernándezArevalo et al. 2005; Alfaro-Ramírez et al. 2017). P. hartwegii also forms a monospecific forest with dispersed trees of other Pinus, Quercus, Arbutus, and Juniperus species. The understory is dominated by grass species, such as Pestemon gentianoides (Kunth) Poir., Eupatorium glabratum (Kunth), Baccharis conferta (Kunth), Muhlenbergia quadridentata (Kunth), M. macroura (H.B.K.) Hitchc., Festuca tolucensis (H.B.K.), and F. hephaestophila (Nees ex Steud), yet some Lupinus species are also present in small patches (Rzedowski 1998). Forests in the Nevado de Toluca are under great human pressure due to extractive activities and land use, including grazing and arable land; furthermore, $P$. hartwegii timber is highly demanded in furniture manufacturing and construction wood (Franco et al. 2006; Pérez-Suárez et al. 2018).

\section{Field sampling}

Randomized stratified sampling was conducted along an elevation gradient from 3,400 m, the lower limit of $P$. hartwegii in the area, to 4,000 m. Seven sampling points ("elevation plots") were set every $100 \mathrm{~m}$ in elevation along the northeastern face of the Nevado de Toluca Volcano (Fig. $1 \mathrm{C}$; Table 1). Elevation plots were selected as homogenous as possible in terms of slope and forest conditions (i.e., no fire impacts, pests, or any other type of forest disturbance or tree damage). Accessibility was an important issue because of very steep slopes in some areas along the elevation transect. At each elevation plot, we selected 10 healthy $P$. hartwegii trees with diameter at breast height $(\mathrm{DBH})$ ranging between 20 and $50 \mathrm{~cm}$, without any sign of physical damage on the trunk (cuts, burn scars, or pests). Two $15 \mathrm{~cm}$-deep soil samples were collected, $50 \mathrm{~cm}$ away from the base of the trunk, both above and below the slope of each selected tree, using polyvinyl chloride (PVC) tubes $16 \mathrm{~cm}$ in length and $10 \mathrm{~cm}$ in diameter. PVC tubes were embedded with the help of two hammers, hitting simultaneously on both sides to insert them homogeneously into the soil. Twenty samples were taken per plot, for a total of 140 soil samples. Additionally, the sampled-tree diameter was identified and considered in the analyses as well as the diameter and height of each tree recorded at each plot.

\section{Soil analysis}

For each soil sample, the following variables were measured: Bulk Density (BD), Soil Organic Matter (SOM), Soil Organic Carbon (SOC), pH, and texture (reported as clay, silt, and sand content). BD of undisturbed soil samples was determined following the cylinder method. Each soil sample was weighed, after which the soil was taken out from the PVC tubes. Rocks and visible organic material were removed by hand, and each component was weighted. The soil samples were then passed through a $2 \mathrm{~mm}$ sieve. SOM content was determined following the oxide-reduction method (Walkley and Black 1934) and subsequently the SOC content was estimated. SOC stocks were obtained using the following equation: SOC stocks $=\left(\mathrm{SOC}(\%)\right.$ * BD $\left(\mathrm{g} \mathrm{cm}{ }^{-3}\right)$ * Depth $(\mathrm{cm})$ * 100), where Depth was the depth of the extracted sample $(15 \mathrm{~cm})$. Results are reported in $\mathrm{Mg} \mathrm{C} \mathrm{ha-1.} \mathrm{Soil} \mathrm{pH} \mathrm{was} \mathrm{measured} \mathrm{with} \mathrm{1:2} \mathrm{solutions} \mathrm{of} \mathrm{1-} \mathrm{N} \mathrm{KCl} \mathrm{using}$ an OAKTON pH/CON500 potentiometer previously calibrated with $\mathrm{pH} 4,7$, and 10 buffer solutions. Soil texture was analyzed following the Bouyoucos method (Bouyoucos 1962). The results were analyzed using the United States Department of Agriculture's textural triangle (USDA 2014). In addition, normal climate 
variables MAT and mean annual precipitation (MAP) were obtained from the ClimateNA model v5.10 (Wang et al. 2016) for the location of each elevation plot where the soil was sampled, using the site coordinates captured with a GPS device.

\section{Data analysis}

In order to identify significant differences between the seven elevation plots, a one-way ANOVA was carried out for the soil traits (SOC stocks, SOM, BD, pH, sand, clay, and silt content). Normality tests were previously applied for all continuous variables, confirming adjustment to a normal distribution.

Subsequently, linear regression analyses were conducted to identify the influence of the elevation and its different trends on the SOC stocks and the other soil traits (SOM, BD, pH, sand, clay, and silt) obtained from topsoil samples under $P$. hartwegii forest along the elevation gradient. The two soil samples taken from each selected tree (above and below the slope) were averaged, using 70 pieces of data for each soil variables in the statistical analysis. The association degree between soil traits, tree height, and DBH of sampled trees was determined by the Pearson correlation coefficient through the data obtained at the elevation plots. Consecutively, in order to describe the variation between trees across elevation plots, a PCA was performed using the 70 pieces of data. To avoid the multicollinearity effect, a variable was removed from the pairs of variables that were highly correlated $(r>0.90)$. The degree of association between soil, climatic (MAT and MAP), and vegetation structure variables (Table 1) was also determined (Table 2). In order to identify the main variables influencing SOC stocks along the elevation gradient, a multiple regression analysis was conducted considering SOC stocks as the dependent variable, while independent variables were arranged in two groups. Group one included mean values of SOM, BD, pH, sand, clay, silt, and DBH of sampled-trees at each sampling point (i.e., the 10-trees each elevation plot). The second group, associated with climatic variables and vegetation structure, included MAT, MAP, trees diameter, tree height, tree density, grass cover, canopy cover, as well as herbs and shrubs density, at each elevation plot.

Finally, due to evidence of timber harvesting on the sampled plots (extraction of trees, pruning, and grassland burning), a dichotomous qualitative variable ("logged" and "not-logged") was used to evaluate logging effects on soil and vegetation throughout a one-way ANOVA and a multiple logistic regression, where soil traits, vegetation variables and climatic variables were associated with this dichotomous qualitative variable. The logged plots were located from 3,400 to $3,800 \mathrm{~m}$ in elevation, while the non-logged plots included the 3,900 and $4,000 \mathrm{~m}$ elevation plots. All statistical analyses were conducted using the R project version 4.0.3 and the JMP version 8 (SAS Institute, Inc. 2008), with a confidence level of $95 \%$ ( $a \leq 0.05$ ), except for Pearson's correlations, which were tested with confidence levels of $99 \%(a \leq 0.01)$ and $95 \%$.

\section{Results}

\section{SOC stocks and soil properties along the elevation gradient}

The elevation plots were significantly different for most soil traits. The highest SOC stocks $\left(173.0 \pm 5.2 \mathrm{Mg} \mathrm{C}^{-1}\right)$ were recorded at the highest elevation site $(4,000 \mathrm{~m})$, with $16 \%$ less at 3,700 m, where the lowest SOC stocks ( $146.8 \mathrm{Mg} \mathrm{C} \mathrm{ha}^{-1}$ ) were found. In the same way as SOC, the highest amount of SOM (5.13 \pm $0.06 \%)$ was also found at the highest elevation. The lowest $\mathrm{pH}$ was registered at 3,900 $\mathrm{m}(4.92 \pm 0.11)$. Sand content was relatively similar from $3,400 \mathrm{~m}$ to $3,700 \mathrm{~m}$, but increased from $3,700 \mathrm{~m}$ to $3,800-4,000 \mathrm{~m}$. The clay fraction was lowest at $3,900 \mathrm{~m}(13.7 \pm 0.97 \%)$ and highest at $3,400 \mathrm{~m}(18.7 \pm 0.74 \%) ;$ while silt content was lowest to $3,800 \mathrm{~m}(23.12 \pm 1.15)$ and the highest content $(26.04 \pm 0.38 \%)$ at $3,400 \mathrm{~m}$.

SOC stocks in topsoil $(0-15 \mathrm{~cm})$ under $P$. hartwegii forest along the elevation gradient were significantly related to elevation $\left(r^{2}=0.70, p=0.02\right.$; Fig. 3$)$, i.e., elevation explains $70 \%$ of the spatial variability in SOC stocks with a confidence level of $95 \%(F i g .3)$. SOM displayed an elevation trend $\left(r^{2}=0.55, p=0.01\right)$ consistent with SOC stocks (Fig. 4 A), except sand content. All other soil variables measured in this study (BD, pH, clay, and silt) did not show any significant elevation trend (Fig. 4 B, C, E, F), having the lowest and highest mean values at different intermediate elevations depending on the variable. Sand content exhibited a significant and positive linear relationship ( $r^{2}=0.72, p=0.01$, Fig. 4 D) with elevation, recording the highest sand content $(63.30 \pm 1.40 \%$, Fig. 4 D) at $4,000 \mathrm{~m}$.

The first principal component from the PCA explains $38.56 \%$ of the total variability and is made up of tree height and sand, then BD and SOC stocks (Fig. 5 A). The second principal component explains $17.06 \%$ of the total variability and is mostly clay and silt, with pH being less involved (Fig. $5 \mathrm{~A}$ ). Consecutively, trees located at higher elevations $(3,800 ; 3,900$ and $4,000 \mathrm{~m})$ showed greater dispersion, grouping towards PC1, while at the lower elevations $(3,400 ; 3,500$ and 3,600 $\mathrm{m})$ trees were less dispersed and clustered towards PC2. Finally, in the center of the gradient $(3,700 \mathrm{~m})$ trees were clustered together but separated from the rest (Fig. 5 B).

\section{Relationship between elevation, soil properties, climate, and vegetation structure}

Considering all variables measured, elevation was significantly and positively associated with SOC stocks $(r=0.84, p=0.04$, Table 2$)$, SOM $(r=0.74, p=0.04)$, sand content $(r=0.85, p=0.03)$ and DBH of sampled trees $(r=0.83, p=0.04)$, but was negatively associated with MAT ( $r=-0.99, p=0.00)$. SOC stocks also showed a highly significant correlation with SOM $(r=0.96, p=0.01)$, sand content $(r=0.80, p=0.04)$ and DBH of sampled trees $(r=0.95, p=0.00)$, while the association with MAT was negative $(r=-0.84, p=0.04)$, increasing SOC as temperature decreased. SOM was positively correlated with sand content $(r=0.83$, $p=0.04)$ and with DBH of sampled trees $(r=0.91, p=0.00)$, while sand content was negatively correlated with clay content $(r=-0.71, p=0.05)$ and MAT $(r=$ $-0.85, p=0.01)$. A negative relationship was recorded between MAT and MAP $(r=-0.99, p=0.03)$ along the sampled transect. Grass cover increases as tree $(r=$ $-0.82, p=0.02)$, herbs and shrubs density decreases $(r=-0.75, p=0.04)$, while the last two decrease where the trees height was greater $(r=-0.75, p=0.04)$. Finally, by associating climate, soil traits and vegetation structure variables with the dichotomous variable of "logging", it can be observed that it presented a statistically significant relationship with elevation ( $p=0.000, a=0.05$; Fig. 6 A) and MAT ( $p=0.000$; Fig. $6 \mathrm{~J})$. SOC showed a statistically significant relationship (Fig. 6 B) with the management of greater stocks at the "no logged" sites, and consistent relationship between logging - SOM ( $p=0.000$; Fig. $6 \mathrm{C}$ ), logging - sand ( $p=0.000$; Fig. 6 F), and logging - DBH ( $p=0.008$; Fig. $6 \mathrm{I})$. The grass cover and the trees height (Fig. $6 \mathrm{~N})$ were higher in not-logging sites, that is, in the highest elevation sites $(p=0.000)$. 


\section{Discussion}

Mountain forests and their soils provide multiple benefits to the inhabitants of both high and lowlands, including the sustainability of the forest itself. However, today these areas are exposed to the impact of climate warming and selective logging. These, influence the mountain forests capacity to climate warming mitigation by $\mathrm{C}$ capture and storage, and these impacts might depend on the elevation at which these forest occur. In this study, SOC stocks in topsoil under $P$. hartwegii forests increases with elevation, while in the lower elevations the explanation of lowest SOC stocks appears to be confounding, due to environmental and logging factors. Nonetheless, despite we did not measure logging as such and the fact that we do not know the intensity and cutting cycles, results in this study indicate an effect of long-term selective logging not only on the forest structure but also on SOC stocks. Thus, logging has generated not only a greater structural change in $P$. hatwegii stands between 3,400-3,800 m, which show to be younger tree stands at earlier successional stages (higher density of trees, herbs and shrubs, as well as lower tree diameter and height), but also the SOC stocks decrease in an elevation where the species climax should result in higher accumulation of SOC.

\section{Effect of elevation on soil traits}

SOC stocks in topsoil under $P$. hartwegii forests increase with elevation along the $600 \mathrm{~m}$ gradient at the Nevado de Toluca; consistent with this, SOM content also raised as elevation increased, indicating, therefore, that this variable as the most significant in describing SOC stock trends along the elevation gradient. This association is expected because SOM is the main pool of SOC, which depends on two main drivers. One of them is precisely the input of OM to the soil through litterfall production, which is the dominant way of OM transfer from aboveground to the soil (Six et al. 2004; de la Cruz-Amo et al. 2020). The second one is the SOM accumulation given the low temperature at the highest elevations, limiting SOM output through a lower decomposition rate (Garten and Hanson 2006; Davidson and Janssens 2006; Tashi et al. 2016).

Temperature, on the other hand, decreases with elevation and has been reported to significantly influence OM decomposition (Davidson and Janssens 2006; Garten and Hanson 2006; Tashi et al. 2016), explaining up to $95 \%$ of the variability of OM decomposition in high elevation forests (Salinas et al. 2010). In this study, the fact that MAT decreased significantly along the sampled elevation gradient while SOM and SOC stocks increased indicates that the last two are not driven by elevation as such on this mountain forest, but by the lower temperature associated with a higher elevation and its effect on vegetation productivity and OM decomposition (Salinas et al. 2010; Shedayi et al. 2016; Tashi et al. 2016). Temperature reduction has a positive impact on SOC stocks due to a lower rate of litter decomposition, lower turnover rate, and higher SOC residence time at high elevations (Du et al. 2014; Tashi et al. 2016; Becker et al. 2019). For example, Garten and Hanson (2006) found a declining SOM decomposition rate with increasing elevation (335-1,670 m) in a forest at the southern Appalachian Mountains, reporting a longer residence time from 11 to 31 years, which resulted in an increase of SOC stocks with elevation. Conversely, based on a soil incubation experiment, Tian et al. (2016) concluded that SOC residence time (stability of SOC) does not depend on temperature only but on the labile size of SOC. Therefore, the SOC residence time in $P$. hartwegii mountain forests depends not only on temperature increase by climate change but also on the proportion of labile $\mathrm{C}$ in this mountain soils rather than the total SOC.

$\mathrm{BD}$, the second variable explaining most of the SOC stocks variability along the elevation gradient in this study, increased significantly with elevation. BD is typically low $\left(>0.9 \mathrm{~g} \mathrm{~cm}^{-3}\right)$ in volcanic soils such as Andosols due to the dominance of largely weathered volcanic glass in the sand and silt fractions (Delmelle et al. 2015). However, BD is not only related to the density and arrangement of mineral soil (sand, silt, and clay), but also to the OM particles and SOC (Neall et al. 2006; Delmelle et al. 2015). Thus, the role of soil texture in both SOC content and BD is widely known; for example, sandy soils have shown higher BD and lower SOC, while low BD soils tend to have higher OC (Lukac and Godbold 2011). In this study, sand and silt fraction were positively related to elevation, and negatively related to MAT (Table 2). An increase in sand content as elevation increases is expected in mountain volcanic soils (resulting from volcanic ash) where rock weathering and soil formation processes are less intense, resulting in shallower, coarser, and sandier soils at higher elevations (Simon et al. 2018).

Andosols, equivalent to Andisols in the World Reference Base for Soil Resources (WRB), are volcanic soils characterized by their great storage capacity of OC (from 42 to $207 \mathrm{Mg} \mathrm{OC} \mathrm{ha-1}^{-1}$ ) and their stabilization, due to the presence of aluminum-humus complexes in the soil surface horizons (Msanya et al. 2007; Covaleda et al. 2011). However, according to Msanya et al. (2007) and Covaleda et al. (2011), volcanic ash soils also stabilize OC by forming pseudo-sands and silts. Pseudo-sands are derived from short-range ordered materials, resulting from the weathering of volcanic glass and are present in the sand fraction of soils (Msanya et al. 2007). Under the climatic change context, sand content in soils might play an important role on SOC stabilization in high mountain forests because sand content is strongly related to the intermediate $\mathrm{SOC}$ pool from SOM decomposition, which contributes significantly to the cumulative $\mathrm{C}-\mathrm{CO}_{2}$ release (Tian et al. 2016). Therefore, it would be important to explore the role of the sand fraction on potential mechanisms of SOC stabilization in these relatively young volcanic ash soils.

\section{Main drivers of SOC stocks on mountain forest soils from the Nevado de Toluca}

In this study, the fact that the largest trees were found in the highest elevation plot, consistent with the largest amount of SOM and SOC, suggests litter as the main reason why there were greater SOC stocks recorded at the highest elevation, i.e, there is greater litter production at the highest elevation. However, it is well known that plant growth is reduced at higher elevations due to environmental limitations, such as low partial $\mathrm{CO}_{2}$ pressure, short growing seasons, soil nutrients limitations, extremely low temperatures, etc., as reported for $P$. hartwegii (Harsh and Bader 2011; Körner 2015; Alfaro-Ramírez et al. 2017). For this pine species, the climax has been reported at 3,700 m (Perry 1991), and a decrease of tree height and diameter as elevation increases towards the treeline ecotone (from 3,980 to 4,130 m) has been shown at the northwest and east-southeast side of the volcanic cone of the Nevado de Toluca, as per the findings of Alfaro-Ramírez et al. (2017). Although this last study was performed on a different side of the Nevado de Toluca (northeastern side) where the ecotone occurs at a much higher elevation, what was reported by Alfaro-Ramírez and collaborators, is an indicator of the limiting conditions to the $P$. hartwegii growth as elevation increases. Thus, the fact that we found the largest trees and highest SOC stocks at the high elevation plots, and not as expected at 3,700 $\mathrm{m}$, indicates that other external factors have modified the $P$. hartwegii forest structure as well as the SOM input and the SOC residence time. Change in forest 
structure is also supported by the highest herbs and shrub density, and the lowest grass cover, not typical of $P$. hartwegii forests at low elevations. According to Challenger (1998), typical $P$. hartwegii forests have a relatively simple structure, with only one tree layer and few or no herbs and shrubs in the understory. Jafari et al. (2013), report similar results with respect to that factors such as harvesting and selective logging, that modified vegetation structure, have a stronger effect in lower elevation forestlands than in higher.

In general, changes in the plant community due to natural or anthropogenic causes have a major impact on SOC stocks (de la Cruz-Amo et al. 2020). These mountain forests have been under big anthropogenic pressure for a long time. Timber from $P$. hartwegii has been in great demand for commercialization of furniture's and construction wood (most of them unauthorized), the largest and highest trees ( $>35 \mathrm{~cm}$ and $>20 \mathrm{~m}$, respectively) being the most utilized (Franco et al. 2006). On the other hand, illegal logging occurs in a much lesser degree on the upper area, the buffer zone of the PAFF of the Nevado de Toluca. The logging restrictions allow the permanence of large trees, contrary to the low elevations (up to 3,700 $\mathrm{m}$ ) where we found the smaller trees and where the forest is more degraded because of the different human activities. Thus, the lack of protection and implementation of the law means that there are no mechanisms to control illegal logging and its impact on the capacity of these forests and their soils to store OC. SOC losses of about $8 \%$ due to logging have been reported in temperate forests (Nave et al. 2010). Logging effects on SOC stocks topsoil can be direct and indirect; tree removal directly reduces $\mathrm{OM}$ input to the soil, and indirectly affects decomposition rate, modifying litter quality and microsite conditions (Pérez-Suárez et al. 2012). Logging modifies litter quality input to the soil by creating canopy gaps that promote secondary succession in the understory, i.e., it increases the presence of easily decomposable herbs and shrubs (less recalcitrance), limiting SOM pools (Cepáková and Frouz 2015; Bomfim et al. 2020). Microsite conditions are also altered when canopy gaps increase the light incidence and temperature on the forest floor (Coletta et al. 2017; Bomfim et al. 2020). This increases litter decomposition rate and, hence, the heterotrophic respiration and the continuous $\mathrm{C}_{-} \mathrm{CO}_{2}$ outputs from the soil (Six et al. 2004 ; Coletta et al. 2017) for a long time (up to 45 years) after logging (Chiti et al. 2016).

In summary, SOC stocks along the elevation gradient are controlled through the elevation effect on MAT and soil texture. The results suggest that SOC stocks in high elevation soils occur due to lower temperatures that allow long-term SOC accumulation which is simultaneously promoted through microsite conservation by restrictions on forest exploitation; conversely, at lower altitudes, changes in forest structure strongly reduce SOC stocks. Based on this study, soils under mountain forests not only should be considered in the carbon inventories but also in conservation and differential reforestation programs according to the elevation gradient. Elevation and forest management activities, as important drivers of SOC stocks, could make it possible to keep the greatest SOC reservoirs and long-term mountain forest sustainability.

\section{Conclusions}

Elevation had a significant positive effect on the distribution of topsoil SOC along $P$. hartwegii elevation gradient at the Nevado de Toluca. A positive elevation effect was also observed for SOM pools, sand content, and tree diameter, while MAT was found to decrease with elevation. Spatial variability of SOC stocks along the elevation gradient appears to be mainly controlled by SOM, BD, and MAT. However, our results also suggest that this control differs according to the elevation range. In this manner, at low elevations (from 3,500 to 3,800 m) selective timber extraction may have modified microsite environment, increasing SOC outputs, while at high elevations (from 3,900 to 4,000 m) lower MAT reduced the decomposition rate and ultimately decreased SOC stocks. Nonetheless, it is important to deepen our knowledge about the control of SOM and SOC dynamics along elevation gradients, as well as to elucidate the role of temperature and other mechanisms in SOC stocks regulation and stabilization in mountain forest topsoil, including tree extraction. In particular, additional research is needed to understand how global warming could impact SOC stocks in alpine forest ecosystems and how unplanned and/or excessive logging could exacerbate its effect.

\section{Abbreviations}

C: Carbon

SOC: Soil organic carbon

m: meters above sea level

SOM: soil organic matter

BD: bulk density

$\mathrm{pH}$ : potential of hydrogen

ANOVA: Analysis of variance

$\mathrm{Mg} \mathrm{ha}^{-1}$ : Megagrams per hectare

MAT: Mean annual temperature

MAP: Mean annual precipitation

Pg: pentagrams

$\mathrm{N}$ : nitrogen 
$\mathrm{CO}_{2}$ : Carbon dioxide

PAFF: Protected Area of Flora and Fauna

DBH: Diameter at breast height

PVC: Polyvinyl chloride

PC: Principal components

WRB: World Reference Base for Soil Resources

\section{Declarations}

\section{Ethics approval and consent to participate}

The subject has no ethic risk.

\section{Consent for publication}

Not applicable.

\section{Availability of data and material}

Data are available from the corresponding author on reasonable request.

\section{Competing interests}

The authors declare that they have no known competing financial interests or personal relationships that could have appeared to influence the work reported in this paper.

\section{Funding}

This research work was funded by CONACYT-Basic Science's Grant No. 219696. The Authors are also grateful to CONACYT for granting an MS scholarship to LCA (No. 746226).

\section{Authors' contributions}

This research was initiated and conceptualized by MPS, who also did the supervision, project administration and funding acquisition. LCA did the formal analyses, methodology, data curation, and writing-original draft. MPS, JJVH and PR participated in visualization, supervising statistical analyses and reviewing and editing the manuscript. The author (s) read and approved the final manuscript.

\section{Acknowledgements}

Thanks also to CEPANAF and CONANP for allowing us to access the APFF Nevado de Toluca.

\section{Authors' information (optional)}

'Not applicable'

\section{References}

1. Alfaro-Ramírez FU, Pérez-Suárez M, Arredondo-Moreno JT, Endara-Agramont AR (2017) Pinus hartwegii Lindl. Treeline ecotone: Structure and altitudinal limits at Nevado de Toluca. Mexico Rev Chapingo Ser Cienc For y del Ambient 23:261-273. doi:10.5154/r.rchscfa.2016.10.055

2. Alfaro-Ramírez FU, Ramírez-Albores JE, Vargas-Hernández JJ, Franco-Maass S, Pérez-Suárez M (2020) Potential reduction of Hartweg's Pine (Pinus hartwegii Lindl.) geographic distribution. Plos One 15:e0229178. doi:10.1371/journal.pone.0229178

3. Becker JN, Dippold M, Andreas H, Kuzyakov Y (2019) Ashes to ashes: Characterization of organic matter in Andosols along a $3400 \mathrm{~m}$ elevation transect at Mount Kilimanjaro using analytical pyrolysis. Catena 180:271-281. doi:10.1016/j.catena.2019.04.033

4. Beniston M, Diaz H, Bradley RS (1997) Climatic Change at High Elevation Sites: An Overview. Clim Change 36:233-251. doi:10.1023/A:1005380714349

5. Berg B, Meentemeyer V (2002) Litter quality in a north European transects versus carbon storage potential. Plant Soil 242:83-92. doi:10.1023/A:1019637807021

6. Bohra CS, Tewari SK, Bhatt MD (2014) Trends in soil carbon stockpile of three major forests along an altitudinal gradient in Indian Central Himalaya. Ecoprint 21:7-13. doi:10.3126/eco.v21i0.11898

7. Bomfim B, Silva LCR, Pereira RS, Gatto A, Emmert F, Higuchi N (2020) Litter and soil biogeochemical parameters as indicators of sustainable logging in Central Amazonia. Sci Total Environ. doi:10.1016/j.scitotenv.2020.136780 
8. Bouyoucos GJ (1962) Hydrometer method improved for making particle size analyses of soils. Agron J 54:464-465. doi:10.2134/agronj1962.00021962005400050028x

9. Cepáková S, Frouz J (2015) Changes in chemical composition of litter during decomposition: a review of published ${ }^{13} \mathrm{C}$ NMR spectra. J Soil Sci Plant Nut 15:805-815. doi:10.4067/S0718-95162015005000055

10. Challenger A (1998) Utilización y conservación de los ecosistemas terrestres de México: pasado, presente y futuro. Comisión Nacional para el Conocimiento y Uso de la Biodiversidad; UNAM, Instituto de Biología. México

11. Challenger A, Soberón J (2008) Los ecosistemas terrestres. En Comisión Nacional para el Conocimiento y Uso de la Biodiversidad (CONABIO) (Eds.), Capital Natural de México, vol. I: Conocimiento actual de la biodiversidad, pp 87 - 108. México: CONABIO

12. Chiti T, Perugini L, Vespertino D, Valentini R (2016) Effect of selective logging on soil organic carbon dynamics in tropical forests in central and western Africa. Plan Soil 399:283-294. doi:10.1007/s11104-015-2697-9

13. Coletta V, Pellicone G, Bernardini V, De Cinti B, Froio G, Marziliano PA, Matteucci G, Ricca N, Turco R, Veltri A (2017) Short-time effect of harvesting methods on soil respiration dynamics in a beech forest in southern Mediterranean Italy. iForest 10:645-651. doi:10.3832/ifor2032-010

14. CONANP (2016) Programa de Manejo del Área de Protección de Flora y Fauna Nevado de Toluca. Toluca, México. https://simec.conanp.gob.mx/pdf_libro_pm/104_libro_pm.pdf. Accessed 20 Feb 2021

15. Covaleda S, Gallardo JF, García-Oliva F, Kirchmann H, Prat C, Bravo M, Etchevers JD (2011) Land-use effects on the distribution of soil organic carbon within particle-size fractions of volcanic soils in the Transmexican Volcanic Belt (Mexico). Soil Use Manage 27:186-194. doi:10.1111/j.14752743.2011.00341.x

16. Cruz-Cardenas G, López-Mata L, Silva JT, Bernal-Santana N, Estrada-Godoy F, López-Sandoval JA (2016) Potential distribution model of Pinaceae species under climate change scenarios in Michoacán. Rev Chapingo Ser Cienc For y del Ambiente 22:135-148. doi:10.5154/r.rchscfa.2015.06.027

17. Davidson EA, Janssens IA (2006) Temperature sensitivity of soil carbon decomposition and feedbacks to climate change. Nature 440:165-173. doi:10.1038/nature04514

18. de la Cruz-Amo L, Bañares-de-Dios G, Cala V, Granzow-de la Cerda I, Espinosa Cl, Ledo A, Salinas N, Macía MJ, Cayuela L (2020) Trade-Offs Among Aboveground, Belowground, and Soil Organic Carbon Stocks Along Altitudinal Gradients in Andean Tropical Montane Forests. Front Plant Sci 11:106. doi:10.3389/fpls.2020.00106

19. Delmelle P, Opfergelt S, Cornelis J, Pieng C (2015) Suelos volcánicos. In: La enciclopedia de los volcanes, [online] Rhode Island: Haraldur Sidgurdsson, pp 1253-1264. https://www.sciencedirect.com/science/article/pii/B9780123859389000729. Accessed 8 October 2020

20. Dixon RK, Solomon AM, Brown S, Houghton RA, Trexier MC, Wisniewski J (1994) Carbon pools and flux of global forest ecosystems. Science 263:185190. doi:10.1126/science.263.5144.185

21. Du B, Kang H, Pumpanen J, Zhu P, Yin S, Zou Q, Wang Z, Kong F, Liu C (2014) Soil organic carbon stock and chemical composition along an altitude gradient in the Lushan Mountain, subtropical China. Ecol Res 29:433-439. doi:10.1007/s11284-014-1135-4

22. Dymond CC, Beukema S, Nitschke CR, Coates KD, Scheller RM (2016) Carbon sequestration in managed temperate coniferous forests under climate change. Biogeosciences 13:1933-1947. doi:10.5194/bg-13-1933-2016

23. FAO (2011) Mountain forests in a changing world. Realizing values, addressing challenges. Food and Agriculture Organization of the United Nations, FAO. p 84. http://www.fao.org/3/a-i2481e.pdf. Accesed 27 Feb 2020

24. Franco-Maass S, Regil-García HH, Ordoñez-Díaz JAB (2006) Dinámica de perturbación-recuperación de las zonas forestales en el Parque Nacional Nevado de Toluca. Madera Bosques 12:17-28. doi:10.21829/myb.2006.1211247

25. García E (1990) Carta de climas, Atlas Nacional de México. Universidad Nacional Autónoma de México (UNAM), México

26. Garten CT Jr, Hanson PJ (2006) Measured forest soil C stocks and estimated turnover times along an elevation gradient. Geoderma 136:342-352. doi:10.1016/j.geoderma.2006.03.049

27. Gómez-Mendoza L, Arriaga L (2007) Modeling the effect of climate change on the distribution of oak and pine species of Mexico. Conserv Biol 21:15451555. doi:10.1111/j.1523-1739.2007.00814.x

28. Harsch MA, Bader MY (2011) Treeline form - a potential key to understanding treeline dynamics. Glob Ecol Biogeogr 20:582-596. doi:10.1111/j.14668238.2010.00622.x

29. Heimann M, Reichstein M (2008) Terrestrial ecosystem carbon dynamics and climate feedbacks. Nature 451:289-292. doi:10.1038/nature06591

30. Hernández-Arévalo JC, Gutiérrez GG, Almeida-Leñero L, Ordóñez-Díaz JAB (2005) Análisis dendroclimático de Pinus hartwegii en el volcán Nevado de Toluca. México. I Simposio Ecología, Manejo y Conservación de los Ecosistemas de Montaña en México. Memorias. Laboratorio de Biotecnología y Ecología Aplicada. LABIOTECA. Xalapa, Veracruz, México. Noviembre 17 y 18, 2005. pp 102-103

31. INEGI, Proyección CCL, Datum ITRF92 (2007) Referenciado en la Internacional Base Referencial Mundial del Recurso Suelo (WRB 1999)

32. IPCC (2014) Climate Change 2014: Impacts, Adaptation, and Vulnerability. Part A: Global and Sectorial Aspects. Contribution of Working Group II to the Fifth Assessment Report of the Intergovernmental Panel on Climate Change [Field CB, Barros VR, Dokken DJ, Mach KJ, Mastrandrea MD, Bilir TE, Chatterjee M, Ebi KL, Estrada YO, Genova RC, Girma B, Kissel ES, Levy AN, MacCracken S, Mastrandrea PR, White LL (eds.)]. Cambridge University Press, Cambridge, United Kingdom and New York, NY, USA, p 1132

33. Jafari SM, Zarre S, Alavipanah SK (2013) Woody species diversity and forest structure from lowland to Montane Forest in Hyrcanian Forest Ecorregion. J Mt Sci 10:609-620. doi:10.1007/s11629-013-2652-2

34. James J, Harrison R (2016) The effect of harvest on forest soil carbon: A meta-analysis. Forest 7:308. doi:10.3390/f7120308 
35. Jobbágy E, Jackson R (2000) The vertical distribution of soil organic carbon and its relation to climate and vegetation. Ecol Appl 10:423-436. doi: $10.2307 / 2641104$

36. Kirschbaum MUF (2000) Will changes in soil organic carbon act as a positive or negative feedback on global warming? Biogeochemistry $48: 21-51$. doi:10.1023/A:1006238902976

37. Körner C (2015) Paradigm shift in plant growth control. Curr Opin Plant Biol 25:107-114. doi:10.1016/j.pbi.2015.05.003

38. Körner C (2007) The use of 'altitude' in ecological research. Trends Ecol Evol 22:569-574. doi:10.1016/j.tree.2007.09.006

39. Kumar S, Lal R, Lloyd CD (2012) Assessing spatial variability in soil characteristics with geographically weighted principal components analysis. Computal Geosci 16:827-835. doi:10.1007/s10596-012-9290-6

40. Lukac M, Godbold DL (2011) Soil ecology in Northern forests. A belowground view of a changing world. Cambridge University Press, United Kingdom, p 256

41. Manzanilla-Quiñones U, Aguirre-Calderón OA, Jiménez-Pérez J, Treviño-Garza EJ, Yamellel Y (2019) Distribución actual y futura del bosque subalpino de Pinus hartwegii Lindl. en el Eje Neovolcánico Transversal. Madera Bosques 25:e2521804. doi:10.21829/myb.2019.2521804

42. Maraseni TN, Pandey SS (2014) Can vegetation types work as an indicator of soil organic carbon? An insight from native vegetations in Nepal. Ecol Indic 46:315-322. doi:10.1016/j.ecolind.2014.06.038

43. Mayer M, Prescott CE, Abaker WEA, Augusto L, Cécillon L, Ferreira GWD, James J, Jandl R, Katzensteiner K, Laclau JP, Laganiere J, Nouvellon Y, Paré D, Stanturf JA, Vanguelova El (2020) Influence of forest management activities on soil organic carbon stocks: A knowledge synthesis. For Ecol Manag 466:118127. doi:10.1016/j.foreco.2020.118127

44. Msanya BM, Otsuka H, Araki S, Fujitake N (2007) Characterization of volcanic ash soils in southwestern Tanzania: Morphology, physicochemical properties, and classification. Afr Stud Monogr 34:39-55. doi:10.14989/68484

45. Nave LE, Vance ED, Swanston CW, Curtis PS (2010) Harvest impacts on soil carbon storage in temperate forests. For Ecol Manag 259:857-866. doi:10.1016/j.foreco.2009.12.009

46. Neall VE (2006) Volcanic soils. Encyclopedia of Life Support Systems (EOLSS). Land use and land cover VIl:1-24. http://www.eolss.net/ebooks/ Sample\%20Chapters/C19/E1-05-07-13.pdf. Accessed 12 July 2020

47. Pepin N, Bradley RS, Diaz HF, Baraer M, Caceres EB, Forsythe N, Fowler H, Greenwood G, Hashmi MZR, Liu XD, Miller JR, Ning L, Ohmura A, Palazzi E, Rangwala I, Schöner W, Severskiy I, Shahgedanova M, Wang MB, Williamson SN, Yang D (2015) Elevation-dependent warming in mountain regions of the world. Nat Clim Chang 5:424-430. doi:10.1038/nclimate2563

48. Pérez-Suárez M, Arredondo JT, Huber-Sannwald E (2012) Early stage of single and mixed leaf-litter decomposition in semiarid forest pine-oak: the role of rainfall and microsite. Biogeochemistry 108: 245-258. doi: 10.1007/s10533-011-9594-y

49. Pérez-Suárez M, Flores-Navarro MA, Martínez-Campos AR, Estrada-Flores JG, Chávez-Mejía C (2018) Impact of extensive grazing on supporting and regulating ecosystem services from mountain soils. Mt Res Dev 38:125-134. doi:10.1659/MRD-JOURNAL-D-17-00103

50. Perry JP (1991) The pines of Mexico and Central America. Timber Press. Portland, Oregon, E.U.A, Portland, pp 137-140

51. Rzedowski J (1998) Diversidad y orígenes de la flora fanerogámica de México. En: Ramamoorthy T.P., Bye R., Lot A. y Fa J. Comp. Diversidad Biológica de México: Orígenes y Distribución, pp. 129-145, Instituto de Biología, Universidad Nacional Autónoma de México, México, D.F

52. Salinas N, Malhi Y, Meir P, Silman M, Roman-Cuesta R, Huaman J, Salinas D, Huaman V, Gibaja A, Mamani M, Farfan F (2010) The sensitivity of tropical leaf litter decomposition to temperature: results from a large-scale leaf translocation experiment along an elevation gradient in Peruvian forest. New Phytol. doi:10.1111/j.1469-8137.2010.03521.x

53. Salome C, Nunan N, Pouteau V, Lerch TZ, Chenu C (2010) Carbon dynamics in topsoil and in subsoil may be controlled by different regulatory mechanisms. Glob Change Biol 16:416-426. doi:10.1111/j.1365-2486.2009.01884.x

54. Santini NS, Adame MF, Nolan RH, Miquelajauregui Y, Piñero D, Mastretta-Yanes A, Cuervo-Robayo P, Eamus D (2019) Storage of organic carbon in the soils of Mexican temperate forests. For Ecol Manag 446:115-125. doi:10.1016/j.foreco.2019.05.029

55. SAS Institute Inc (2008) SAS@ Web Report Studio 4.2; User's Guide. SAS Institute Inc, Cary, p 5136

56. Shedayi AA, Xu M, Naseer I, Khan B (2016) Altitudinal gradients of soil and vegetation carbon and nitrogen in a high altitude nature reserve of Karakoram ranges. Springerplus 5:320. doi:10.1186/s40064-016-1935-9

57. Sheikh MA, Kumar M, Bussmann R (2009) Altitudinal variation in soil organic carbon Stock in coniferous subtropical and broadleaf temperate forests in Garhwal Himalaya. Carbon Balance Manag 4:1-6. doi:10.1186/1750-0680-4-6

58. Simon A, Dhendup K, Rai PB, Gratzer G (2018) Soil carbon stocks along elevational gradients in Eastern Himalayan mountain forests. Geoderma Reg 12:28-38. doi:10.1016/j.geodrs.2017.11.004

59. Six J, Bossuyt H, Degryze S, Denef K (2004) A history of research on the link between (micro)aggregates, soil biota, and soil organic matter dynamics. Soil Till Res 79:7-31. doi:10.1016/j.still.2004.03.008

60. Six J, Feller C, Denef K, Ogle SM, de Moraes JCS, Albrecht A (2002) Soil organic matter, biota, and aggregation in temperate and tropical soils -Effects of no-tillage. Agronomie 22:755-775. doi:10.1051/agro:2002043

61. Spracklen DV, Righelato R (2014) Tropical montane forests are a larger than expected global carbon store. Biogeosciences 11:2741-2754. doi:10.5194/bg-11-2741-201

62. Swetnam TL, Brooks PD, Barnard HR, Harpold AA, Gallo EL (2017) Topographically driven differences in energy and water constrain climatic control on forest carbon sequestration. Ecosphere 8:e01797. doi:10.1002/ecs2.1797

Page 9/16 
63. Tashi S, Singh B, Keitel C, Adams M (2016) Soil carbon and nitrogen stocks in forest along an altitudinal gradient in the Easter Himalayas and a metaanalysis of global data. Glob Change Biol 22:2255-2268. doi:10.1111/gcb.13234

64. Tewksbury CE, Miegroet HV (2007) Soil organic carbon dynamics along a climatic gradient in a southern Appalachian spruce fir forest. Can J Forest Res 37:1161-1172. doi:10.1139/X06-317

65. Tian Q, He H, Cheng W, Bai Z, Wang Y, Zhang X (2016) Factors controlling soil organic carbon stability along a temperate forest altitudinal gradient. Sci Rep 6:18783. doi:10.1038/srep18783

66. Tito R, Vasconcelos HL, Feeley KJ (2020) Mountain ecosystems as natural laboratories for climate change experiments. Front For Glob Change 3:1-8. doi:10.3389/ffgc.2020.00038

67. USDA (United States Department of Agriculture) (2014) Soil Survey Staff, $12^{\circ}$. ed. US-Environmental Protection Agency, Washington, p 140

68. Walkley A, Black IA (1934) An examination of Degtjareff method for determining soil organic matter, and a proposed modification of the chromic acid titration method. Soil Sci 37:29-38

69. Wang T, Hamann A, Spittlehouse D, Carroll C (2016) Locally Downscaled and Spatially Customizable Climate Data for Historical and Future Periods for North America. Plos One 11:e0156720. doi:10.1371/journal.pone.0156720

70. Wiesmeier M, Urbanski L, Hobley EU, Lang B (2019) Soil organic carbon storage as a key function of soils - A review of drivers and indicators at various scales. Geoderma 333:149-162. doi:10.1016/j.geoderma.2018.07.026

71. Zhang M, Zhang X, Liang W, Jiang Y, Dai G, Wang X, Han S (2011) Distribution of soil organic carbon fractions along the altitudinal gradient in Changbai Mountain, China. Pedosphere 21:615-620. doi:10.1016/S1002-0160(11)60163-X

72. Zhu B, Wang X, Fang J, Piao S, Shen H, Zhao S, Peng C (2010) Altitudinal changes in carbon storage of temperate forests on Mt Changbai, Northeast China. J Plant Res 123:439-452. doi:10.1007/s10265-009-0301-1

\section{Tables}

Table 1 General characteristic of sampling sites in P. hartwegii forest along an elevation gradient from 3,400 to 4,000 m at Nevado de Toluca.

\begin{tabular}{|c|c|c|c|c|c|c|c|c|}
\hline $\begin{array}{l}\text { Elevation } \\
\text { (m a.s.l) }\end{array}$ & $\begin{array}{l}\text { Average terrain slope } \\
\text { (\%) }\end{array}$ & $\begin{array}{l}\text { Slope } \\
\text { aspect }\end{array}$ & $\begin{array}{l}\text { Canopy } \\
\text { cover } \\
(\%)\end{array}$ & $\begin{array}{l}\text { Tree density (trees } \\
\mathrm{ha}^{-1} \text { ) }\end{array}$ & $\begin{array}{l}\text { Tree } \\
\text { height } \\
\text { (m) }\end{array}$ & $\begin{array}{l}\text { Tree } \\
\text { diameter } \\
\text { (m) }\end{array}$ & $\begin{array}{l}\text { Grass cover } \\
(\%)\end{array}$ & $\begin{array}{l}\text { Herb and shrub } \\
\text { density } \\
\text { (plants ha-1) }\end{array}$ \\
\hline 4,000 & $\begin{array}{l}13.44 \\
( \pm 0.94)\end{array}$ & Northeast & 45 & $\begin{array}{l}306.25 \\
( \pm 131.10)\end{array}$ & $\begin{array}{l}10.61 \\
( \pm 2.76)\end{array}$ & $\begin{array}{l}0.30 \\
( \pm 0.01)\end{array}$ & 73 & 0 \\
\hline 3,900 & $\begin{array}{l}14.37 \\
( \pm 3.16)\end{array}$ & Northeast & 43 & $\begin{array}{l}243.75 \\
( \pm 90.36)\end{array}$ & $\begin{array}{l}10.35 \\
( \pm 0.69)\end{array}$ & $\begin{array}{l}0.23 \\
( \pm 0.01)\end{array}$ & 80 & 0 \\
\hline 3,800 & $\begin{array}{l}10.94 \\
( \pm 1.86)\end{array}$ & Northeast & 103 & $\begin{array}{l}1400.00 \\
( \pm 619.67)\end{array}$ & $\begin{array}{l}9.99 \\
( \pm 3.92)\end{array}$ & $\begin{array}{l}0.20 \\
( \pm 0.06)\end{array}$ & 49 & 0 \\
\hline 3,700 & $\begin{array}{l}17.81 \\
( \pm 3.08)\end{array}$ & Northeast & 48 & $\begin{array}{l}1250.00 \\
( \pm 459.09)\end{array}$ & $\begin{array}{l}5.63 \\
( \pm 0.65)\end{array}$ & $\begin{array}{l}0.11 \\
( \pm 0.02)\end{array}$ & 31 & $\begin{array}{l}250 \\
( \pm 135.02)\end{array}$ \\
\hline 3,600 & $\begin{array}{l}11.04 \\
( \pm 1.96)\end{array}$ & Northeast & 87 & $\begin{array}{l}706.25 \\
( \pm 336.24)\end{array}$ & $\begin{array}{l}6.66 \\
( \pm 1.15)\end{array}$ & $\begin{array}{l}0.16 \\
( \pm 0.03)\end{array}$ & 84 & $\begin{array}{l}37.50 \\
( \pm 37.50)\end{array}$ \\
\hline 3,500 & $\begin{array}{l}25.94 \\
( \pm 3.51)\end{array}$ & Northeast & 50 & $\begin{array}{l}425.00 \\
( \pm 186.63)\end{array}$ & $\begin{array}{l}8.48 \\
( \pm 2.12)\end{array}$ & $\begin{array}{l}0.18 \\
( \pm 0.04)\end{array}$ & 70 & $\begin{array}{l}37.50 \\
( \pm 37.50)\end{array}$ \\
\hline 3,400 & $\begin{array}{l}17.19 \\
( \pm 1.48)\end{array}$ & Northeast & 69 & $\begin{array}{l}406.25 \\
( \pm 69.97)\end{array}$ & $\begin{array}{l}7.16 \\
( \pm 1.20)\end{array}$ & $\begin{array}{l}0.23 \\
( \pm 0.04)\end{array}$ & 73 & $\begin{array}{l}31.25 \\
( \pm 31.25)\end{array}$ \\
\hline
\end{tabular}

Table 2 Pearson correlation coefficients between physical and chemical topsoil properties, climatic (MAT and MAP) and vegetation structure variables recorded along the elevation gradient in $P$. hartwegii forest at Nevado de Toluca. 
SOC

BD

$\mathrm{pH}$

Sand

Clay Silt MAT

MAP Canopy Tree density

DBH of Tree sampled heig

\begin{tabular}{|c|c|c|c|c|c|c|c|c|c|c|c|c|c|c|}
\hline Elevation & $0.84^{*}$ & 1 & & & & & & & & & & & & \\
\hline som & $0.96 * \star$ & $0.74^{*}$ & 1 & & & & & & & & & & & \\
\hline BD & 0.29 & 0.64 & 0.1 & 1 & & & & & & & & & & \\
\hline $\mathrm{pH}$ & -0.59 & -0.59 & -0.73 & 0.08 & 1 & & & & & & & & & \\
\hline Sand & $0.80 *$ & $0.85^{\star}$ & $0.83^{*}$ & 0.51 & -0.71 & 1 & & & & & & & & \\
\hline Clay & -0.5 & -0.62 & -0.53 & -0.3 & $0.74^{\star}$ & $-0.71 *$ & 1 & & & & & & & \\
\hline Silt & -0.53 & -0.73 & -0.39 & $-0.77^{\star}$ & 0.28 & -0.67 & $0.78^{\star}$ & 1 & & & & & & \\
\hline MAT & $-0.84^{*}$ & $-1.0 * \star$ & -0.74 & -0.63 & 0.59 & $-0.85^{\star}$ & 0.62 & $0.73^{*}$ & 1 & & & & & \\
\hline MAP & -0.51 & 0.24 & -0.45 & -0.21 & 0 & -0.36 & 0.24 & 0.42 & $-0.99 * *$ & 1 & & & & \\
\hline $\begin{array}{l}\text { Canopy } \\
\text { cover }\end{array}$ & -0.28 & -0.23 & -0.30 & 0.45 & 0.35 & 0.06 & 0.04 & -0.21 & 0.23 & -0.46 & 1 & & & \\
\hline Tree density & -0.35 & 0.01 & -0.54 & 0.75 & 0.64 & -0.12 & 0.15 & -0.38 & -0.01 & 0.04 & 0.58 & 1 & & \\
\hline $\begin{array}{l}\text { DBH of } \\
\text { sampled } \\
\text { trees }\end{array}$ & $0.95^{\star \star}$ & $0.83^{*}$ & $0.91^{\star \star}$ & 0.33 & -0.65 & $0.82^{\star}$ & -0.69 & -0.67 & $-0.83^{\star}$ & -0.58 & -0.18 & -0.32 & 1 & \\
\hline Tree height & $0.77 *$ & 0.68 & $0.84^{\star}$ & 0.21 & $-0.75^{\star}$ & $0.88^{*}$ & $-0.84^{\star}$ & -0.65 & -0.68 & -0.45 & -0.09 & -0.33 & $0.83^{*}$ & 1 \\
\hline Grass cover & 0.26 & -0.06 & 0.44 & -0.53 & -0.62 & 0.21 & -0.25 & 0.23 & 0.06 & -0.32 & -0.05 & $-0.82^{*}$ & 0.34 & 0.33 \\
\hline $\begin{array}{l}\text { Herb and } \\
\text { shrub } \\
\text { density }\end{array}$ & 0.46 & 0.18 & 0.63 & 0.13 & 0.63 & -0.6 & 0.58 & 0.25 & 0.18 & 0.63 & -0.26 & 0.5 & -0.56 & -0.7 . \\
\hline
\end{tabular}

SOC: Mg C ha-1 ${ }^{-1}$ Elevation: $\mathrm{m}$ a.m.s.l., SOM: \%, BD: $\mathrm{g} \mathrm{cm}^{-3}$, Sand: \%, Clay: \%, Silt: \%, MAT: ${ }^{\circ} \mathrm{C}, \mathrm{MAP}: \mathrm{mm}$, Canopy cover: \%, Tree density: trees ha ${ }^{-1}$, Tree height: $\mathrm{m}$, Sampled trees diameter: $\mathrm{cm}$, Grass cover: \%, Herb and Shrub density: plants ha ${ }^{-1}$.

* Significant Correlation at $95 \%$ of confidence $(a \leq 0.05)$.

** Significant Correlation at $99 \%$ of confidence $(a \leq 0.01)$.

\section{Figures}




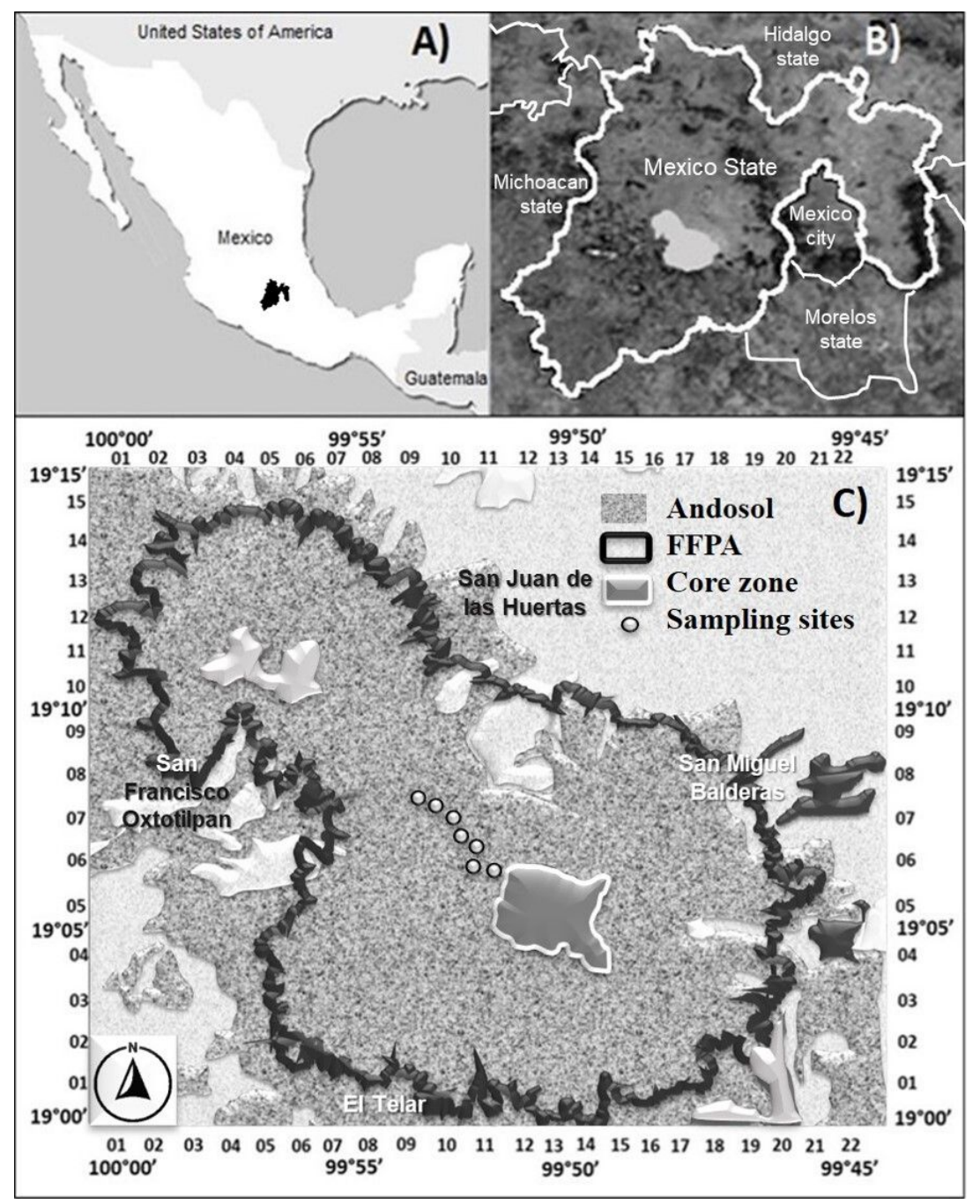

\section{Figure 1}

Geographic location of Mexico (A); Area for the Protection of Flora and Fauna "Nevado de Toluca”, State of Mexico (B); Location of sampling sites with soil types (C), classified according to INEGI (2007). 


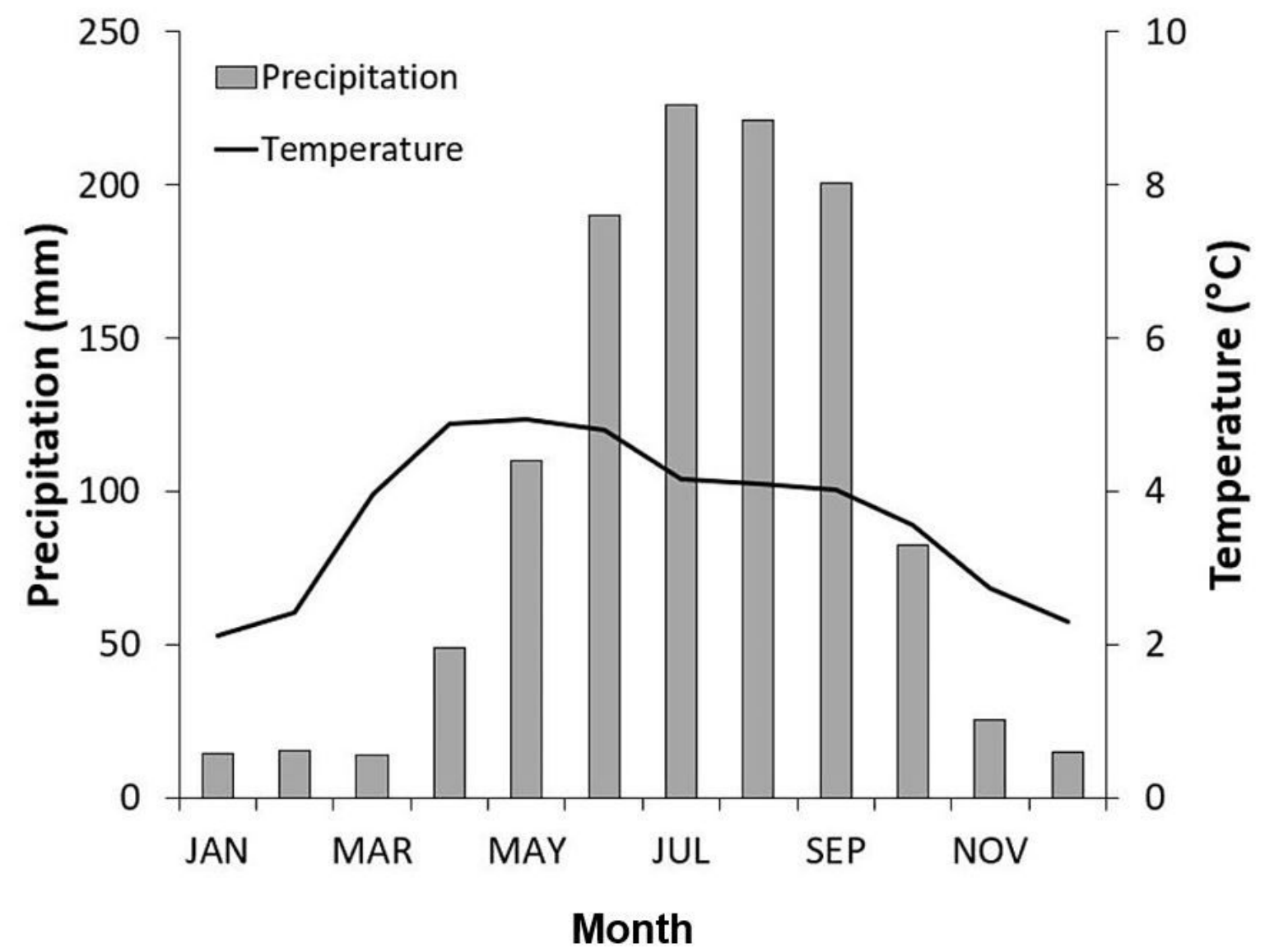

Figure 2

Climogram with data for the 1961-2016 period obtained from the Nevado de Toluca meteorological station located at elevation of 4,139 m (1907'33" $\left.99^{\circ} 46^{\prime} 15^{\prime \prime}\right)$.

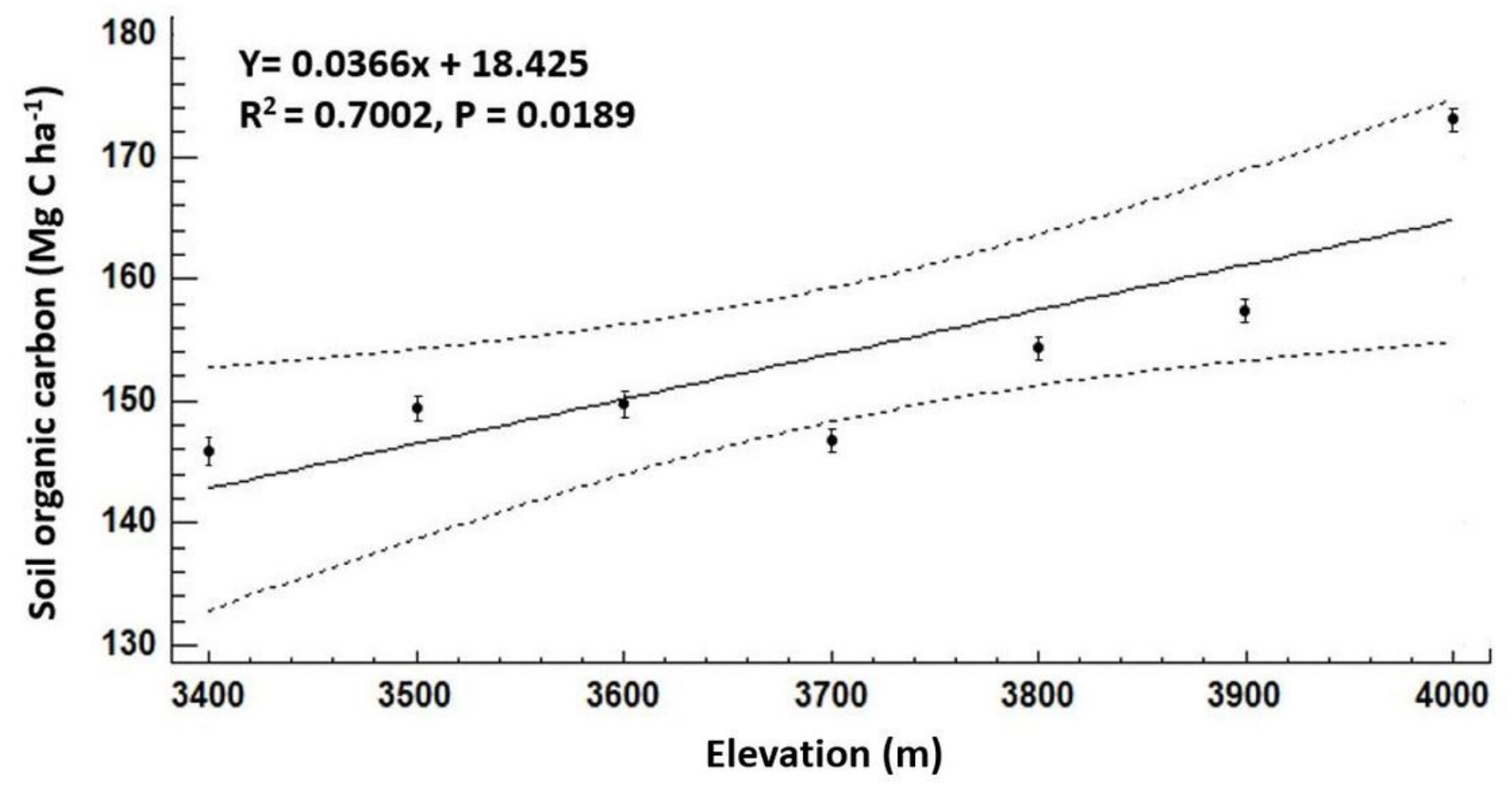


Soil organic carbon (SOC) stocks in topsoil $(0-15 \mathrm{~cm})$ under P. hartwegii forest along an elevation gradient of $600 \mathrm{~m}$ (3,400 to 4,000 m) at Nevado de Toluca (n $=140)$. Means \pm S.E. are reported. Dotted lines represent the $95 \%$ confidence interval.
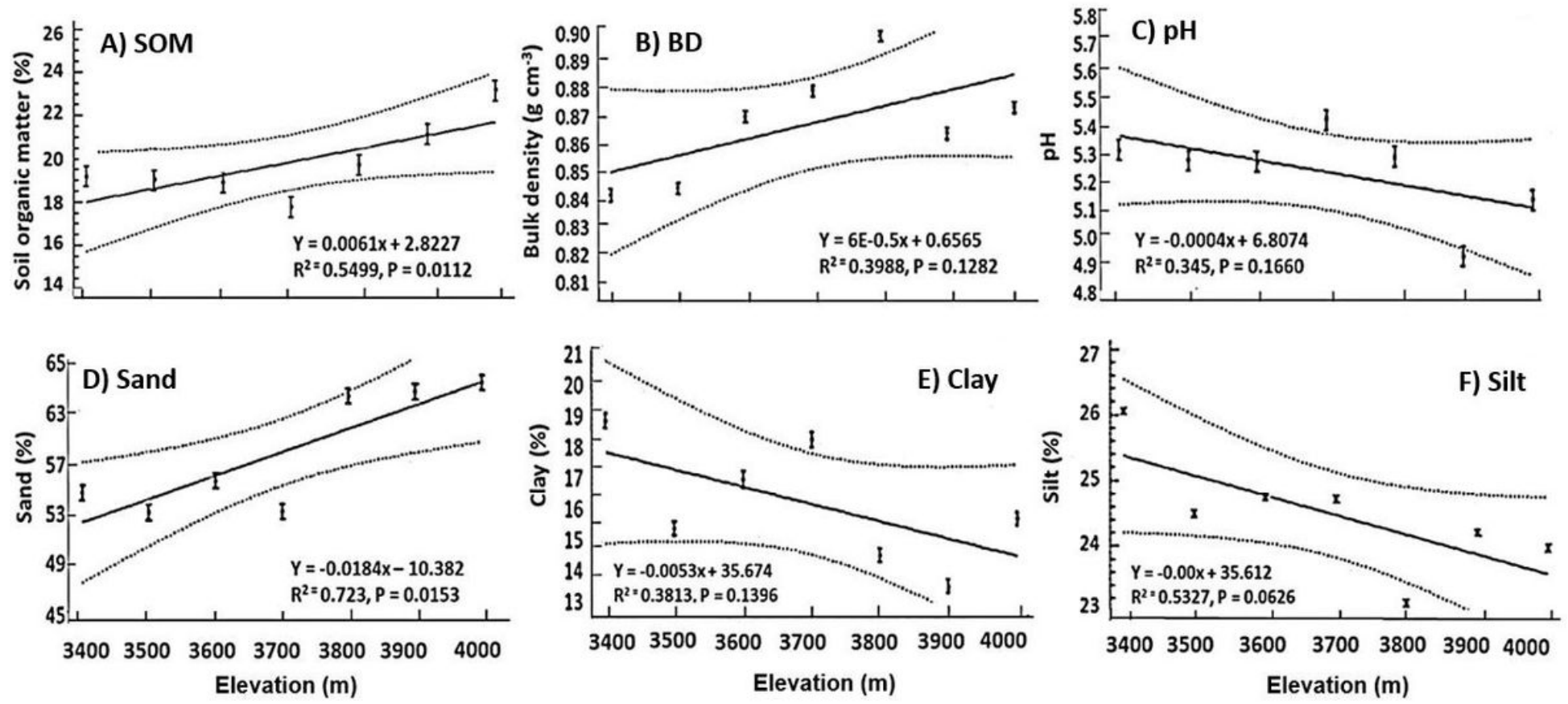

Figure 4

Soil organic matter (SOM, A), bulk density (BD; B), pH (C), clay content (D), silt content (E), and sand content (F) of topsoil (0-15 cm) under P. hartwegii forest along an elevation gradient of $600 \mathrm{~m}(3,400$ to $4,000 \mathrm{~m})$ at Nevado de Toluca $(n=140)$. Means \pm S.E. are reported. Dotted lines represent the $95 \%$ confidence interval. 

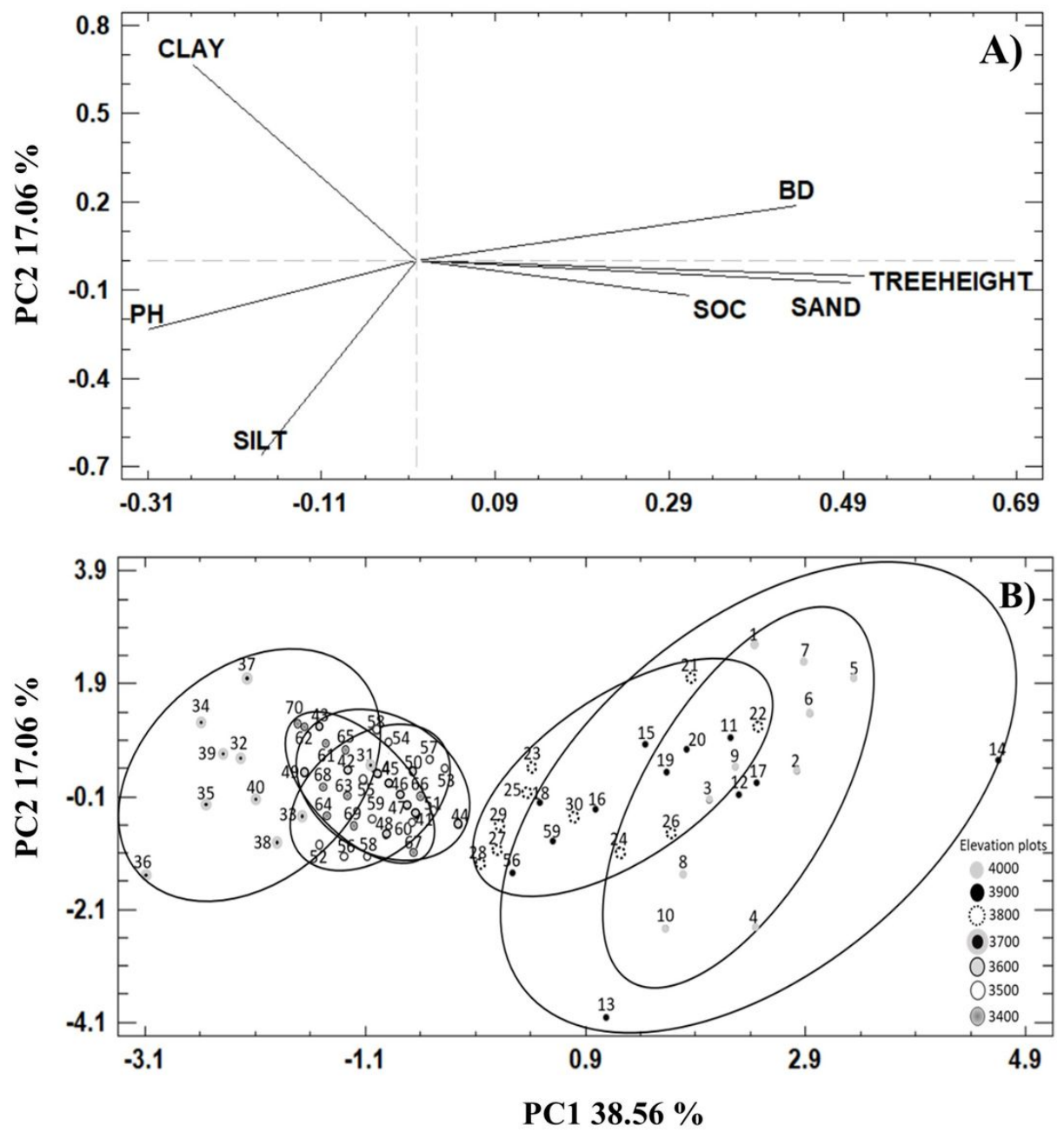

\section{Figure 5}

Relationship between main original variables with the first two PCs, indicating the orientation of the variable groups towards PC1 or PC2 (A), and spatial variation of the sampling points relative to the first two PCs, to explain the structure and pattern of variation of the original variables evaluated at the sampling sites (B). 

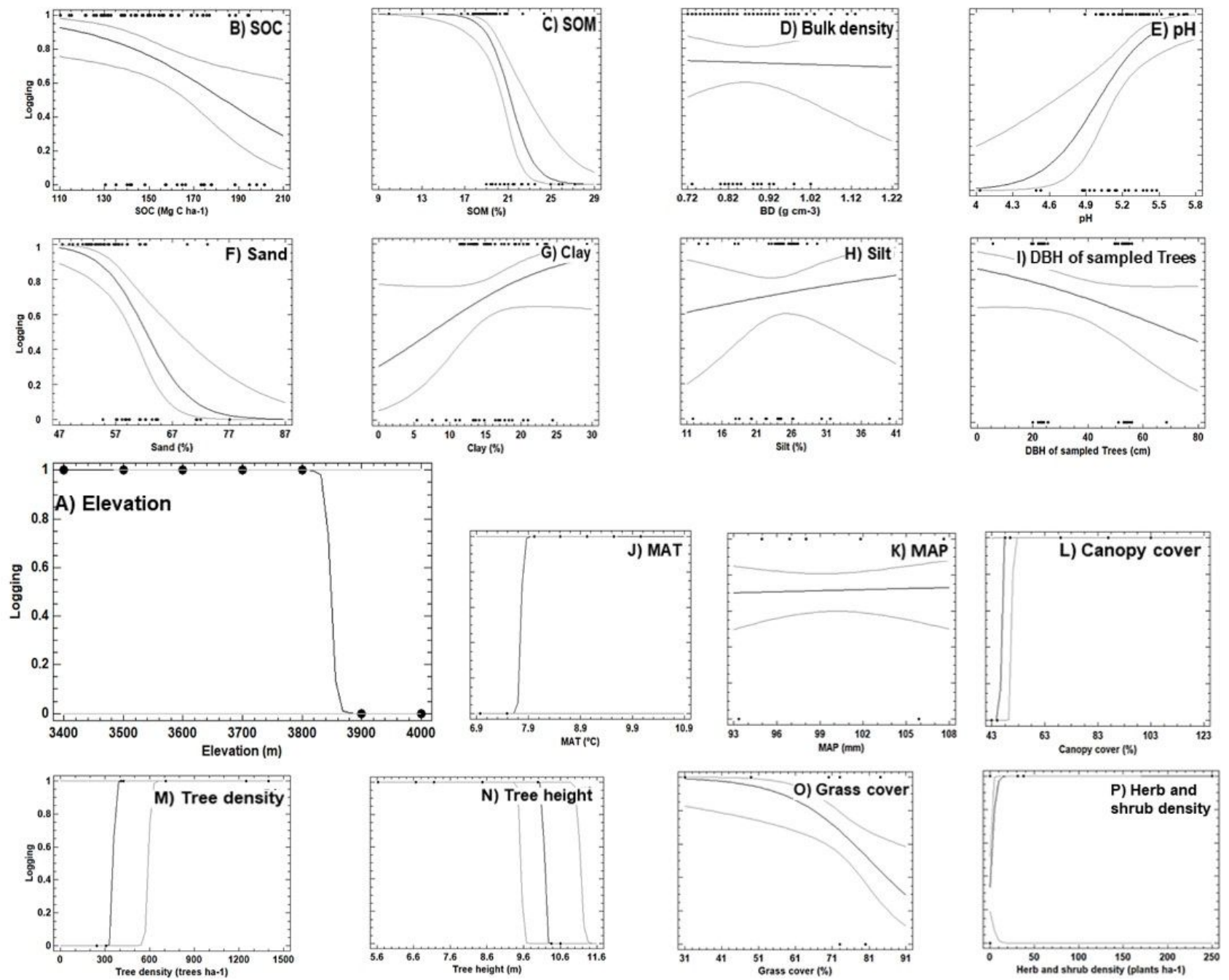

Figure 6

Association between soil traits $(B, C, D, E, F, G, H)$, climate variables $(J, K)$, and vegetation structure features $(I, L, M, N, O, P)$ with logging along the elevation gradient $(A)$ of $P$. hartwegii forest. 